\title{
The Fall of the Family-State and Rise of the Enterprise Society: Family as Ideology and Site of Conservative Power in Modern Japan
}

\author{
Julian Brook Ruszel* \\ University of Victoria \\ julianbrook1@gmail.com
}

\begin{abstract}
Recent literature on the history of family in Japan reveals that what is commonly understood as the "traditional" Japanese family — called the $i e$ family - is largely a political construct that was institutionalized in Japan's Meiji period (1868-1912). While the ie model was effectively removed from the US-imposed postwar constitution and replaced with the western nuclear family as the new ideal, this historical analysis reveals that the neo-Confucian principles and social structures of the ie model were reintegrated into Japan's company work culture, to the degree that the $i e$ continued to shape Japan's collectivist social structures and identities well beyond the end of the war. This analysis highlights key ideologies employed by the ruling elite in modern Japan as a means of social control and nation building. It demonstrates a continuation of the historically close relationship between family and the state in postwar Japan that challenges deterministic notions of westernization applied to the Japanese context; it highlights articulations of family that complicate culturally bound conceptions that see it as inherently separate from the state, and clarifies the modern history of collectivist society in Japan.
\end{abstract}

Keywords: Japan; family; ideology; collectivism; feminism

\section{Introduction}

W

hile the modern family's connection to capitalist and patriarchal state power in western nations is well established among feminist scholars (see, for example, Eisenstein, 1999; MacKinnon, 1989), in recent Japanese history the family has been an especially overt target of political intervention, functioning as both an ideological and structural site of conservative, capitalist state power ${ }^{1}$ Two time periods - the Meiji (1868-1912) and postwar (1945-1973) periods - represent key turning points when conservative politicians and ideologues strongly rearticulated family as a means of maintaining political and social control in the face of rising liberal and socialist influences in Japan. More specifically, they rearticulated a traditional samurai family model in order

\footnotetext{
${ }^{*}$ With special thanks to the Jamie Cassels Undergraduate Research Award, Dr. Andrew Marton, who acted as JCURA supervisor, and Dr. Richard Fox and Dr. Sujin Lee for their support and guidance.

1 "Conservative" here includes a belief in the preservation of Confucian values in modern Japan and a negative stance towards social change and liberal values, including democracy and women's rights and equality.
} 
to reproduce patriarchal and hierarchical collectivist social structures that would serve elite conservative interests and also support the emerging Japanese capitalist system. This research analyses the distinct family structures, forms of family-centered social control, and patriarcho-capitalist social formations that emerged in these two periods, and is informed by a socialist feminist conception of the modern family as simultaneously a patriarchal and capitalist construct (see Eisenstein, 1999).

The term ideology, as it is employed in this discussion, refers pragmatically to an organized set of ideas connected to a particular class or group (see Freeden, Stears, \& Van Dijk, 2013). However, inasmuch as the mark of an effectively mobilized ideology is its level of tacit acceptance as truth - as knowledge - across a large section of society, then ideology must also be understood as always containing a certain discursive potential to become so socially embedded as to organize action and thought, and ultimately shape individuals as particular subjects (see Freeden, Stears, \& Norval, 2013; Freeden et al., 2013b; Mouffe, 1979). This understanding of ideology is pertinent to the Japanese historical context because politically driven ideological constructions of family and nation produced in the Meiji period came to be tacitly accepted as reflecting a natural gendered and hierarchical order, and finally became embedded in beliefs and social practices that persist to this day (see Kondo, 1990; Ueno, 2009).

The following discussion demonstrates the ideological means that Japan's ruling elite employed to manage social change in the Meiji and postwar periods. They rearticulated family and nation within an ideological framework that effectively reoriented the public towards service of the conservative state, supported their political goal of building a strong nation and army, and ensured the continuation of their privileged positions as patriarchs and aristocrats. This politico-ideological strategy is encapsulated in the Meiji family-state (kazoku kokka) ideology that merged a Confucian family model with a Shinto conception of the imperial state. At the heart of this ideology was a new family model, called the ie (pron. ee-eh), which was a rearticulation of the gendered and hierarchical Confucian social structures that the Tokugawa regime had used to maintain order from 1603 to 1868 (Lebra, 2007). The $i e$ represented a patrilineal family inheritance system and a household unit predicated on the Confucian principles of patriarchal paternalism and filial piety. As a household operation, it was an inherently collectivist structure that strongly reflected the structurally mediated social relations of Confucianism and its negation of personal emotions and impulses. Within the Meiji family-state ideology, the $i e$ would also be tied to a jingoistic rearticulation of Japan's indigenous Shinto religion that reimagined Japan as a racially homogenous imperial nation-state, where the emperor ruled as the spiritual father of all Japanese citizens (Gluck, 1985; Skya, 2009). Additionally, a teaching known as the "good wife, wise mother" (ryōsai kenbo) ideology specifically interpellated women's identities within the $i e$ household (Lebra, 2009). This gendered ideology's evolution in the interwar period represents an important bridge between the Meiji and postwar periods, and it would remain central to women's roles and identities after the Second World War. Finally, despite ostensible liberal reforms in the postwar period-including the legally-sanctioned imposition of the western nuclear family model - the ruling elite successfully rearticulated family in a way that merged the modern nuclear family with the principles of the Meiji era family model to advance a new "enterprise society" (Garon, 2010, p. 332) supported by the gendered and hierarchical power relations institutionalized in the Meiji period. In other words, both the Meiji and postwar governments employed ideological constructions of family to perpetuate and exploit the feudal power structures and subservient collectivist subjectivities of feudal Japan.

Whereas some scholars have suggested that modernization is antithetical to the values of Japan's "traditional" family system (see Yamane \& Nonoyama, 1967), the values of that system were in fact central to modernization in Japan and were a foundational aspect of Japan's postwar enterprise society; the neo-Confucian principles and social structures of the $i e$ were reconfigured to support Japan's company work culture in the postwar period, to the degree that the ie model and its 
constituent gendered roles and identities continued to shape Japan's collectivist social structures and identities well beyond the end of the war.

\section{Oligarchy and Threats to Conservative Power in the Meiji Period}

In 1858, Tokugawa Shogunate officials gave in to western imperial pressure and opened nine ports for trade with the US and other western nations (Gordon, 2014). Prior to this, the Tokugawa regime had forbidden trade and social relations with most foreigners since the first half of the 17th century. Less than a decade later, in 1867, the Tokugawa Shogunate was overthrown by a relatively small group of disgruntled sub-elite samurai from two marginal domains located in the southwestern region of Japan.

After forming a new government, the leaders of these two samurai clans - the Choshu and Satsuma clans - would immediately commence dismantling the feudal domain and samurai status systems that had upheld Tokugawa power for over 250 years. Though worthy of being dubbed revolutionary reformers in that they overthrew the oligarchs of the old social order and set about "modernizing" Japanese society, these new leaders of the nascent Japanese nation-state were nonetheless highly conservative aristocrats who ultimately sought to establish themselves as Japan's new ruling oligarchs (Beckmann, 1957; Tabb, 1995).

Tellingly, just prior to enacting Japan's first constitution in 1889, the Meiji political elite set up an extra-constitutional "Privy Council" from which they could continue to exercise executive power over the newly created bicameral legislature (called the Diet), and subsequently created a number of other self-serving positions in the constitution (Beckmann, 1957; Gordon, 2014). As George Beckmann (1957) writes,

For all practical purposes ... the influential leaders of Choshu and Satsuma controlled the government through their positions in the cabinet, the supreme command, the Privy Council, and the Imperial Household Ministry, all of which constituted the actual repositories of executive power. Thus the Meiji Constitution, from one point of view, established an oligarchical clan control in a modern political form. (pp. 89-90)

From these protected seats of power, according to Gordon (2014), the Meiji political elite would go on to "pull the strings [of Japanese politics] for the rest of their lives" (p. 92), and become known among their detractors as the "Meiji oligarchs" (p. 92) and the "Sat-Cho dictatorship" (p. 81).

Despite the increasingly popular efforts of Japanese activists to gain support for a democratic government in Japan, Japan's new oligarchs proved to be extremely shrewd political operators who consolidated autocratic control while effectively steering social change in Japan. Instead of increasing public participation and implementing the democratic government many in the public were demanding, the Meiji oligarchs delivered a constitution meant to "maximize the power of the state and minimize that of the people" (Gordon, 2014, p. 92). Additionally, on the eve of the promulgation of the constitution, the government issued a series of laws banning women from engaging in any form of political activity, a measure that would be strongly reinforced a decade later in a repressive Public Peace Police Law (Chian Keisatsu Hō) (Mackie, 2003). Indeed, even as the Meiji oligarchs embraced the logics of capitalism and industrialization, their words and actions revealed a deep enmity towards the political and social values of the West.

Near the peak of a popular rights movement that had been gaining momentum across Japan throughout the 1870s, Yamagata Aritomo, who would go on to serve two terms as prime minister, corresponded with fellow ex-Choshu samurai and Japan's first — and fifth, seventh, and tenth — prime minister, Ito Hirobumi, writing, "Every day we wait, the evil poison [of popular rights agitation] will spread more and more over the provinces, penetrate into the minds of the young, and inevitably 
produce unfathomable evils" (Gordon, 2014, p. 84; see "Prime Ministers in History," n.d.). Hozumi Yatsuka, a passionate imperial loyalist and key intellectual contributor to the notion of the Japanese family-state ideology, firmly rejected all notions of individualism and popular rights in Japan and insisted that sovereignty remain solely in the emperor (Skya, 2009). Responding to the founding of the Eastern Socialist Party ( Tōyō Shakai Tō), Hozumi wrote,

If these fanatics are already steeped in socialism, wandering about in heresy, and beyond morality, then it is useless to dispute with them about right and wrong by appealing to the judgment of logic. Yet if, now when people's hearts are immoderate, there should be many who with fearfully clever arguments seek to give free reign to private desires, then it is to be expected that unhappy results will follow. (as cited in Skya, 2009, p. 54)

Hozumi's anti-individualist and anti-socialist thinking reflected popular conservative views throughout the Meiji period and beyond. An article in the Tokyo Asahi newspaper in 1911 warned strongly of the dangers to Japan's national character posed by "the penetration of extreme individualism [and] the outbreak of socialism, which execrates those in power" (as cited in Gluck, 1985, p. 188). Yamagata would later collaborate with Hozumi to implement official government policies aimed at suppressing individualism and socialism through national education initiatives operating with the explicit goal of "developing national thought and excluding individualism" by cultivating "healthy thought' in teachers, pupils, and texts" (Gluck, 1985, p. 177).

In response to a barrage of perceived threats to their conservative vision of Japanese society - and challenges to their positions as patriarchs and aristocrats - the Meiji oligarchs turned to the Confucian ideological heritage and power structures of their samurai background, which necessarily included the "rigid class relations modeled on that of master and servant" (Howland, 2001, p. 367) that had characterized samurai power in the Tokugawa period. Importantly, the oligarchs turned to particular meanings of family that neatly embodied all of these elements, combining a neo-Confucian samurai family model with a vision of Japan as an imperial family-state. The resultant family-state ideology would become central to the reconsolidation of oligarchic power in the Meiji period, and ultimately shape modern Japan.

\section{Confucianism and Shinto Rearticulated in the Meiji Family-State Ideology}

After consolidating their control over the government with the Meiji Constitution of 1889, the Meiji oligarchs collaborated with conservative intellectuals to consolidate their power within Japanese society itself. They would implement a new vision of Japanese society predicated on a notion of Japan as a family-state, wherein the $i e$ samurai family model became intrinsically connected to the emperor, who was elevated as the father of all Japanese people and the essence of the Japanese state (Gluck, 1985; Skya, 2009; Ueno, 2009).

The Meiji family-state ideology would be articulated in such a way as to inform every level of society, from family and education, to business practices, the military, and policing (see Garon, 2010; Gluck, 1985; Rohlen, 1974; Ueno, 2009). This ideology represented a shrewd rearticulation of Confucian and Shinto ideologies; it reflected the oligarchs' elite Confucian, samurai background, and was largely their response to what they perceived as threats to their vision of Japanese society (see Gluck, 1985; Gordon, 2014; Howland, 2001; Ueno, 2009). The family-state ideology and its constituent family model came about through a series of efforts - beginning almost immediately after the fall of the Tokugawa Shogunate - and represent a modern ideology predicated on historical power structures in Japanese society. 
One of the first official initiatives carried out by the Meiji oligarchs following the revolution of 1867 was the implementation of a nationwide family registry system, called the koseki, that documented every individual as belonging to a registered household and placed authority over the family in the male head of each household (Garon, 2010). The koseki emphasized the importance of the family as a collective entity and allocated certain rights to individuals based on their membership within a registered household (Sugimoto, 2010). It would be refined over two decades later in the Civil Code of 1898 with the institutionalization of the ie, the samurai family model that the government decided would support its conservative vision of Japanese society. Interestingly, the koseki remains in use in Japan to this day and continues to define the Japanese family (see Sugimoto, 2014).

The koseki and its constituent family system represented one of many steps the government would take to extend its reach into the private sphere of Japanese citizens' lives. Tellingly, a moral text from 1887 sponsored by the Ministry of Education called The Meiji Greater Learning for Women (Meiji onna daigaku) explicitly stated, "The home is a public place where private feelings should be forgotten" (Nolte \& Hastings, 1991, p. 156). It is important to clarify that this did not represent a novel form of political overreach but rather a reconfigured continuation of the power structures of feudal Japan; as opposed to being separate and protected from the larger society, families in feudal Japan often acted as agents of institutional power, even prioritizing state authority over family members (see Sakuta, 1986). Keiichi Sakuta (1986) and Chizuko Ueno (2009) separately observe that this power dynamic carried over into modern Japan. While Ueno also clarifies that the sharp division between the public and private spheres in the West is itself a relatively recent result brought about by modernity, Kaori Hayashi (2006) asserts that the European sense of the concept of the "public" as belonging to private individuals still has not fully taken root in Japan and still carries negative connotations there.

In Meiji Japan, it seems the political elite had the benefit of being in a position to proactively manage the emergence of the private sphere. They did so in a way that perpetuated the close relationship between family and the state that existed in feudal Japan, which had been largely predicated on limiting the power of individuals. This helps explain why the Meiji oligarchs and conservative scholars like Hozumi Yatsuka were so adamantly opposed to individualism, as it represented a reversal of the feudal power dynamic that was still supporting oligarchic power in Japan. This also helps explain why, after the koseki was established in 1872, family remained a central focus for many politicians and scholars. While many ideologues initially turned to romanticized visions of village life as an antidote to the perceived ills of modernization, this fascination with the "verities of the past" (Gluck, 1985, p. 178) naturally led to a focus on the utility of the family as a cultural and political tool.

Two conservative ideologues in particular made significant contributions to the rise of Japan's family-state ideology and the $i e$ family model as it was employed in the Meiji period: Motoda Nagazane and the previously mentioned Hozumi Yatsuka. Perhaps the most significant contribution came from Motoda, a highly influential Confucian scholar and Privy Council member who had been a first-grade lecturer (jiko) to the emperor since 1881 ("Motoda Nagazane," n.d.). Motoda's strongly imperialist rearticulation of Confucianism would ultimately form the basis for the institutionalization of Confucianism (or rather, neo-Confucianism) in the Meiji period (Ueno, 2009).

In 1879, Motoda published Kyōgaku taiko (General principles of education), wherein he emphasized a Confucian teaching that connects people's loyalty to the emperor with the filial piety they display towards their parents (Ueno, 2009). As Ueno points out, the notions of filial piety $(k \bar{o})$ and loyalty $(c h \bar{u})$ were ranked in accordance with their traditional Confucian prioritization in Kyōgaku taiko - that is, filial piety was placed before loyalty. However, in 1882 Motoda published Yōgaku kōyō (The elements of education for the young), in which he shrewdly reversed the order of 
filial piety and loyalty and combined them in a single compound word, chūko (loyalty-filial piety). This move represented a significant subversion of the relatively more traditional Confucianism that had been institutionalized in the Tokugawa period, wherein the concepts were separate and filial piety explicitly outweighed loyalty to any monarch. A year later the Japanese government produced modern Japan's first moral textbook, based on Motoda's views, in which it was emphasized that Japanese citizens should "serve the monarch just like they serve their parents" (Ueno, 2009, p. 66).

Motoda would go on to draft the monumental Kyoiku Chokugo (Imperial Rescript on Education), which would be published in 1890 and placed in every school until the end of the Second World War in 1945 ("Danshaku Motoda Nagazane," n.d.; Ueno, 2009). The Kyōiku Chokugo explicitly constructed Japan as a family-state by elevating the emperor to the position of the father of all Japanese people and institutionalizing $c h \bar{u} k \bar{o}$ as the basic core value that would be transmitted to all Japanese citizens beginning in childhood. Prior to this, the government had already begun establishing the infrastructure to ensure they could control the education of young Japanese citizens. They had implemented a system of compulsory education in 1872 - even extending it to women in order to train them as "good wives and wise mothers" - and enrollment numbers were skyrocketing towards the end of the century (Mackie, 2003). In this way, Motoda's Kyōiku Chokugo would become a formative text for Japan's first generation of literate citizens.

Hozumi Yatsuka was, like Motoda, a strong imperial loyalist, and his theories connected individuals and families to the emperor and the Japanese state in ways that echoed Japan's recent feudal past. Hozumi served as a professor of law at Tokyo University from 1889 to 1912 and as the chairman of Tokyo Imperial University's Faculty of Law from 1897 to 1911; he also sat on an influential government committee charged with revising the state's moral education textbooks, which, as mentioned above, had been strongly influenced by Motoda (Skya, 2009; Ueno, 2009). Indeed, as Motoda died in 1891, it would seem Hozumi picked up where he left off, advancing his family-state ideology to its next logical iteration, a racial and religious one.

Hozumi reinterpreted the family-state as a religious ethnic state rooted in a fundamentalist rearticulation of Japan's indigenous Shinto religion. Motoda's notion of $c h \bar{u} k \bar{o}$ would remain central to Hozumi's theory, which combined aspects of Motoda's Confucianism with Shinto mythology to reimagine the Japanese state as a singular ethnic family composed of "blood relatives of the same womb" (Skya, 2009, p. 56). Tying the ie directly to the state and the emperor, Hozumi imagined the Japanese state as "literally one gigantic extended family system composed of interlocking related families," wherein "the [Japanese] people were the emperor's children" (pp. 64-65).

Like Motoda, Hozumi emphasized the role of the Japanese family in society as an extension of the imperial state. However, he paid special attention to ancestral worship, and also went to great lengths to denounce individualism and assert the value of subservient, collectivist subjectivities. He was a strong advocate for the patriarchal authority of the emperor as well as that of the head of the Japanese household, which he described as a "small state" (as cited in Skya, 2009, p. 64). For Hozumi, these institutions necessitated specific collectivist subjectivities; the ideal person was one who had the "desire for total assimilation into the society" and "the purpose of all ethics and morality in the society was to direct the individual to ... acquire the desire to submerge the self totally into the social totality" (Skya, 2009, p. 69). While Hozumi's more radical views were contested at the time, they would help shape the ultranationalist State Shinto (Kokka Shintō) ideology that would be so consequential for Japan in the 20th century.

\section{The Birth of the "Traditional" Japanese Family in Modern Japan}

Importantly, Hozumi would be one of a group of influential conservative scholars to debate which family model should be institutionalized in the Civil Code of 1898. As Gluck (1985) explains, the 
preliminary stage of major institutional reforms in the Meiji period typically involved an "inquiry into Japanese custom" (p. 181). However, such inquiries were strongly informed by ideological goals and, as such, represented fabrications of the past as much as they did objective historical research.

In the debates leading up to the implementation of Japan's first Civil Code, many scholars sought to elevate the quaint customs found in the Japanese countryside as antidotes for the perceived ills of modernization (Gluck, 1985). However, Hozumi and others argued that "the customs of farmers should not be considered customs" (Gluck, 1985, p. 182), and the only true Japanese customs were those of the samurai and the nobility. The government's decision to adopt the $i e$ family model in the Civil Code reflected the ultraconservative views of scholars like Hozumi, as well as the oligarchs' own samurai backgrounds. In this way, the $i e$ was repackaged as Japan's one true "traditional" family, despite the fact that it previously only applied to the samurai families that employed it prior to the Meiji period - who had never made up more than $10 \%$ of the total population (Ueno, 2009).

\section{The Ie and the "Good Wife, Wise Mother" Ideology}

The term ie refers to individual households and also a formal family system because it involves a specifically organized network of patrilineal stem and branch households (collectively called a douzoku), while individual ie households constituted the fundamental documentary unit of the koseki (Kitano, 1962; Lebra, 2007). The koseki itself served as the legal framework with which the $i e$ was enforced as a mandatory family model through the Civil Code of 1898 (Sugimoto, 2014). The ie, as an individual household unit, consisted of two or three generations managed under the authority of a male head of the house. Importantly, the $i e$ household represented a strongly collectivist operation that encapsulated the Confucian principles of patriarchy, filial piety, and rigid, hierarchical social roles, to the point that the $i e$ became the basic vessel for Confucianism in modern Japan. As Takie Lebra (2007) comments, "Confucianism became closely interlocked with the institution of $i e$ so that one was inconceivable without the other" (p. 250). As such, the filial piety and also the paternal authority and reciprocity of Confucianism - where children are expected to respect and obey parents (especially fathers) without question, while parents are expected to provide for, guide, and protect their children - were necessarily central to the ie. This reciprocal paternal relationship defined all relations in the ie, not merely actual parent-child ones, and was contingent on rigidly prescribed social roles rooted wholly in service to the $i e$ and its head.

Indeed, individual needs were subordinate to the needs of the ie, which typically precluded conjugal relations; the husband's duties were centered on his occupation and decisions regarding household management, the wife's main duties were to serve her parents-in-law and support her husband's occupation, and the union of husband and wife was typically the product of a statusmatched arranged marriage (Garon, 2010; Lebra, 2007; Shizuko \& Sylvain, 1994). All members, including the husband, were to be devoted to "the perpetuation of the family as a corporate group through its name and occupation" (Befu, 1965, p. 34). The corporate orientation of the $i e$ is a key feature of the $i e$ family, and it played a major role in the formation of modern Japanese society. As Sheldon Garon (2010) writes,

The Civil Code established the fundamental legal framework governing family relationships, and it powerfully normalized how Japanese conceived of the family before 1945 . The corporate unit of the household reigned above any one individual, constituted as a hierarchy based on gender and age. (p. 326)

In this way, the institutionalization of the $i e$ represented a form of governmentality that not only shaped the meaning and structure of the family, but also interpellated very particular gendered, collectivist subjectivities that supported the family and - as the family became the fundamental 
unit of the family-state - the state itself. Consistent with Hozumi Yastuka's family-state ideology, wherein "the head of the state was really an extension of the father's rights over the family" (Skya, 2009 , p. 65), the $i e$ family would be a powerful tool in the materialization of the imperial family-state ideology and the ascension of the emperor in the public consciousness.

Soon after the institutionalization of the $i e$ in the Meiji Civil Code, educators and commentators began connecting the family to the state and loyalty to the emperor. For example, one school posted a notice to parents urging for proper discipline at home because "when children grow up they care for the parents and raise the fortunes of the family (ie) as well as exert themselves loyally for the ruler and the country" (as cited in Gluck, 1985, p. 188). A magazine article in 1906 commented, "The home, the home (katei katei), everywhere in the country people are paying attention to it now.... Whether one talks of state or society, the foundation is the home, where all social reform must originate" (as cited in Gluck, 1985, p. 189). Between the efforts of the Meiji oligarchs, conservative ideologues like Motoda and Hozumi, and educators and commentators in the Meiji period, the ie family - embedded in a widely promulgated family-state ideology and institutionalized through the legal framework of the koseki - represented a key ideological and structural component that shaped beliefs and social practices in early modern Japan.

In this way, the Meiji oligarchs successfully combined the $i e$ family model with family-state ideology to exploit the "semi-feudal consciousness" (Matanle, 2003, p. 26) of Japanese subjects in the Meiji period, effectively maintaining the feudal power relations that had characterized the relationship between the state and family in the Tokugawa period; the collectivist subjectivities that had supported the hierarchical power structures of Japan's premodern social order would remain central to modern Japanese family, class, and gender power relations. This helps explain why the Japanese family has been referred to as "a valuable agent in fostering conformity to the demands of outside society" (Sakuta, 1986, p. 34) and why "a Japanese patriarch behaves as though he is an agent for the external authority" (Ueno, 2009, p. 67).

After the adoption of the $i e$ family model in the Civil Code, scholar Yanagita Kunio exposed a key theme of the Meiji reforms, saying, "Although we speak of the equality of classes (shimin byōdō), we have imitated the samurai in every way possible" (as cited in Gluck, 1985, p. 182). Indeed, despite the rise of voices calling for progressive reform in Japan, the Meiji oligarchs and imperial loyalists like Motoda and Hozumi ulimately steered much of the energy of social change into an ultraconservative vision of Japanese society based on elite samurai principles and social structures.

As Ueno (2009) points out, the Meiji oligarchs and ideologues were so effective in promoting the ie family as Japan's "traditional" family that contemporary scholars still commonly refer to it as just that, despite its relatively marginal application prior to the Meiji period and the prominence of other family models. Ueno also clarifies the depth of the influence of the $i e$ family model on actual families, as it remains a strong ideal that continues to govern behaviours in Japan's modern nuclear families.

Even as the First World War and social and economic crises swept the nation in the 1920s and 1930s, conservative elites would continue to shape social change according to their principles and goals, efforts that led to a new articulation of the Japanese housewife. A significant Confucian-derived ideological component that arose alongside the promulgation of the family-state ideology and shaped women's roles and identities within the $i e$ household was known as the "good wife, wise mother" (ryōsai kenbo) ideology. Importantly, this ideology became central to conservative rearticulations of the ie's gendered roles and identities in the postwar period. Originally articulated by professional educators and bureaucrats from the Ministry of Education in the wake of the 1894-95 Sino-Japanese War, the "good wife, wise mother" ideology had become the cornerstone of women's education across Japan by 1911 (Uno, 1991). It clearly delineated the sexual division of labour in prewar Japan, interpellating women as dutiful imperial subjects and limiting their roles to "the reproduction and 
socialisation of children, and as passive supporters of a 'wealthy country and strong army'" (Mackie, 2003, p. 3). However, during the First World War, many intellectuals in Japan noted the emerging roles women were playing overseas as labourers supporting war efforts. The resultant theories, combined with the growth of nuclear families in city centers that entailed more central roles for wives, gave rise to a new conception of the "good wife, wise mother" that emphasized the value of women contributing in the labour force, not for equality's sake, but out of national economic and military necessity. And so, while the Meiji oligarchs were able to rearticulate their own samurai family model that emphasized women's natural place in the household, the interwar period saw the ascendance of new conceptions of women's roles that elevated their utility as labourers outside the home. However, even among most progressive intellectuals, the underlying premise of the "good wife, wise mother" ideology that saw women's natural place in the home as mother and wife remained unquestioned, and in fact remains influential in Japan to this day (Shizuko \& Sylvain, 1994).

Ironically, following the devastating defeat of the Second World War and the consequent US-led occupation, the postwar period presented a new opportunity for Japan's ruling elite to respond creatively and comprehensively to what they perceived as continuing challenges to conservative control. While they would have to abandon their previous concerted efforts to preserve the $i e$ as a formal institution, they responded reflexively to changes brought about by war and the growing prominence of the nuclear family in such a way as to preserve its gendered and hierarchical social roles and structures. They would once again invoke a strong ideological rearticulation of family that supported their conservative vision of the Japanese nation-state.

\section{The Fall of the Family-State and Rise of the Enterprise Society}

During the Meiji period and well into the following Taishō period (1912-1926), women were largely subjugated in the ie, while conservative politicians made concerted efforts to keep them disenfranchised from the political realm (Garon, 2010; Tabb, 1995). Legislation prohibiting women from attending any politically related meeting was legislated in 1890 and reinforced in 1900, while the Civil Code itself effectively silenced a small but rising chorus of progressive activists pushing for greater gender equality and conjugal marriages (Garon, 2010; Shizuko \& Sylvain, 1994). While a growing number of intellectuals and politicians began to consider women as politically and economically important at this time, conservative politicians continued to adamantly defend the $i e$ and fight against women's equality into the 1930s. At a parliamentary meeting in 1931, for example, conservative ideologue Ida Iwakusa declared, "The day we grant women the right to vote, they will take their first steps away from the family system and out of the house" (as cited in Garon, 2010, p. 328). Concurring with this perspective, the executive branch of the Diet would vote against allowing women suffrage that same year (Garon, 2010).

It would ultimately take the Second World War to normalize new roles for Japanese women and do away with the $i e$ in the overt institutional sense (Garon, 2010). However, even though the structure of the ie ostensibly gave way to that of the nuclear family, its gendered and hierarchical power relations persisted in important ways. More specifically, the $i e$ family would be neatly supplanted by a "company as family" model that firmly placed the husband's employer (his company) at the center of family life while essentially retaining the sexual division of labour at the heart of the "good wife, wise mother" ideology 2 Indeed, despite the rise of a new central role for women in the home, the basic premise of the "good wife, wise mother" ideology would remain the foundation of Japanese women's roles and identities (Shizuko \& Sylvain, 1994).

\footnotetext{
${ }^{2}$ For a history of the "company as family" and its relationship to the $i e$ in prewar Japan, and insight into its continuing influence in contemporary Japan, see Kondo (1990).
} 
Somewhat ironically, after Japan's hard turn towards imperialism in the 1930s effectively silenced feminist voices calling for greater participation in government and society, the military necessities of the Second World War cemented a new division of labour that placed the husband in direct service of the state and elevated the wife to the role of head of the household (Garon, 2010; Mackie, 2003; Molony, 2011). As Garon (2010) explains,

The conditions of total war further propelled women to the centre of the family. As men were mobilized as labourers and soldiers, millions of women throughout Japan became de facto heads of households in charge of finances and parenting. By the end of the Second World War, women found themselves in charge of local public life as well. (p. 330)

Out of wartime necessity, the state turned to "new measures to persuade mothers to produce healthy workers and soldiers for the nation" (Garon, 2010, p. 330), which necessarily included elevating the wife to the roles of housewife and household manager.

While these new roles were understandably welcomed by many Japanese women, it is important to take note here that this "liberation" from the ie actually represented a significant deepening of state power over women and the family (Garon, 2010). Indeed, this particular shift would be yet another example of the Japanese state's persistent efforts to penetrate the Japanese family and individuals' lives. Echoing the efforts of the Meiji oligarchs with their institutionalization of the $i e$ family, Garon further explains that by the end of the war, "women had come into a direct relationship with the state, permitting the bureaucracy to intervene in daily life more intimately than when male household heads served as the government's principal agents" (p. 330). And so, a new sexual division of labour, along with a new link between families and the state, was forged in the postwar period. Far from representing a true break from the past, the "company as family" social model at the center of Japan's rising "enterprise society" in the postwar period contained striking parallels with the corporate and gendered structure of the $i e$ household and the "good wife, wise mother" ideology, and indicates the ie's basic continuation in a new form in the postwar period (Garon, 2010; Gordon, 1997)

\section{Professional Housewives and the Company as Family}

It is important to note at this point that, just as the Meiji period saw a continuation of elite conservative rule "masked in the rhetoric of renewal" (Tabb, 1995), Japan's defeat in the Second World War and the subsequent American-led Occupation also ultimately resulted in the continuation of Japan's conservative power structures, once again masked as progressive reform. While General MacArthur and the Supreme Commander for the Allies in the Pacific (SCAP) initially worked to dismantle the conservative hold over power and implement strong democratic reforms, rising socialist sentiment, waves of aggressive union actions, and the emergence of the Cold War led SCAP to reverse its course and hand control back to conservative Japanese elites (Lee, 2004; Tabb, 1995). As Tabb (1995) writes, "By the 1950s, the Cold War had changed American priorities, and the former war criminals were allowed, indeed encouraged, to reassert their control, and the leftist unions were mostly smashed" (p. 80) ${ }^{3}$ Renewed conservative social control quickly subverted what might have been Japan's first steps as a truly democratic nation.

As such, while the $i e$ was officially deinstitutionalized alongside State Shinto in the reformed Constitution of Japan in 1947, it is no surprise that the Japanese family would essentially remain

\footnotetext{
${ }^{3}$ One of those held as a suspected Class-A war criminal was Kishi Nobusuke, who would later go on to become prime minister and is current prime minister Abe Shinzo's grandfather. Strikingly, Abe has made it his mission to accomplish what his grandfather could not: overturning the article in the postwar constitution that restricts Japan's military to purely defensive purposes (Dudden \& Mizoguchi, 2007; Osaki, 2019; Yoshida, 2006).
} 
an extension of conservative state power. The rules had changed, however, and so the ruling elite necessarily had to reconfigure their social control strategy; exploiting the new division of labour produced by wartime mobilization, the state would collaborate with the corporate business sector to construct Japan as an "enterprise society" driven by "the economic mobilization of men as producers and women as newly rational ... consumers and household managers" (Gordon, 1997, p. 259).

In this new arrangement, the family would operate as a corporate unit in much the same way as the ie, though its purpose would be refocused on the husband's workplace, and the wife would manage the entire household and raise her children. Much as they did in the ie, Japanese wives would continue to work almost exclusively to raise children and support the success of their husband's occupation from within the home. However, husbands would be required to devote so much time to their work outside the home that - just as during their military service in the war- they would essentially be absent from the Japanese household (Garon, 2010). In these ways, the postwar Japanese family contained striking parallels with the $i e$ household: it would effectively remain free of conjugal relationships and remain predicated on the "natural" sexual division of labour and gendered identities implied by the "good wife, wise mother" ideology.

Just as the ie family and the family-state ideology had been constructed and promulgated by Japan's conservative elite during the Meiji period, so too would this new model be promulgated by elite conservative agents. However, the corporate business sector would play a much more central role in the postwar period. Just as the Meiji state had shaped and penetrated the $i e$ family, so too would the postwar political regime and business elites reach into the newly reconstituted household to guide and shape the ideal housewife, while articulating a new "company as family" model that placed the husband's workplace at the center of the familial corporate unit. The housewife would become a renewed target of such social engineering, to the degree that the housewife-centered family ultimately served "the postwar state's interests in so many realms as to constitute a comprehensive system of governance" (Garon, 2010, p. 332).

One of the key conservative ideologues to popularize these postwar family discourses was Hatoyama Ichirō. Hatoyama had initially been purged from the government by SCAP. However, after SCAP's policy reversal, he returned to serve for two years as prime minister from 1954 to 1956 and help found the Liberal Democratic Party, which would go on to maintain almost uninterrupted political control to this day (Bowen, 2003; Lee, 2004).

As prime minister, Hatoyama adopted an influential corporate campaign called the "New Life Movement" (Gordon, 1997). The New Life Movement sought to mobilize the family - and in particular housewives - to support a new "enterprise society" where "meeting the needs of the corporation is 'naturally' understood to be social common sense and to be congruent with meeting the needs of all society's inhabitants" (Gordon, 1997, p. 247). Echoing the thinking of conservative Meiji ideologues like Hozumi Yatsuka, at a meeting promoting the New Life Movement, Hatoyama urged "industrialists and educators to help renovate both the material and spiritual aspects of peoples' lives and sweep away the deplorable tendencies toward irresponsible liberties and ideologies" (as cited in Gordon, 1997, p. 255).

Following Prime Minister Hatoyama's promotion of the New Life Movement, the state would continue to work closely with Japanese business corporations to reinforce this new vision of Japanese society and family, with a strong focus on community-based training programs aimed at "professionalizing the urban housewife's role" (Gordon, 1997, p. 259); reminiscent of Meiji era educational initiatives and the "good wife, wise mother" ideology, new women's associations and local clubs were organized that trained housewives to be frugal and efficient, while raising their children with "proper" values that supported both the state and enterprise.

The emphasis on frugality as a core value ensured that families would not demand too much of the husband's employer, thus indirectly—but very effectively — silencing truly representative unions 
that sought to elevate workers' wages and quality of life. As Gordon (1997) writes, "the [New Life Movement] worked to preempt or prevent the possibility that home and family would support alternative values to those of enterprise" (p. 259) and ensured that they "would not support radical unions" (p. 261). As a result, the truly labour-based, leftist unions that had gained momentum in the immediate postwar period would be effectively neutered by corporate-friendly "enterprise unions," a dynamic that would continue in Japan to this day (Jeong \& Aguilera, 2008). As such, the New Life Movement would very much fulfill the purposes indirectly set out for Japan's conservatives by MacArthur and SCAP.

While the New Life Movement represented a household-focused reassertion of conservative power that tied the family to the company and essentially articulated a new enterprise-based conception of the Japanese family-state, companies themselves employed practices within the workplace that emphasized the Confucian principles of the ie. The practices both reflected and reinforced the paternalistic power relations that had marked the relationship between state and family in both the Meiji period and feudal Japan (see Tabb, 1997, p. 81).

Thomas Rohlen's (1974) field research on a large Japanese bank in the late 1960s illustrates just how influential the $i e$ family ideology was in postwar Japanese companies. Consistent with the New Life Movement, Rohlen describes how the bank played an active role in family planning. Importantly, Rohlen describes how Japan's Confucian heritage had been transformed into "an institutional rather than a familial morality" (p. 59) and describes a number of parallels between the bank and the ie. Rohlen explains that the traditional Japanese family was an important discourse employed as one of a number of images derived from daily Japanese life used by management to connect with workers on an emotional level. Rohlen writes,

[The bank] is at times referred to as "one great family" (daizoku). The implications of this image are extensive. The bank, like the ideal Japanese family, is an entity in which the interests of the members are secondary to the interests of the family as a whole. It is everyone's interest to work for the well-being and reputation of the family, and in return the family exists for the benefit of all its members. The same relationship holds, by implication, between workers and the bank. (p. 45)

Rohlen goes on to describe the strong paternalism of this corporate family's interpersonal relationships, where leaders take on the responsibility of father figures, while younger members, "out of gratitude and affection, obey and respect their seniors" (p. 46).

Furthermore, and also consistent with both the New Life Movement's and SCAP's anti-socialist goals, Rohlen (1974) touches on how this system necessarily includes the disempowerment of the individual and the exoneration of the company from having to raise the quality of life for its workers. Rohlen writes that in the company, as in Japanese society in general, "satisfaction or unhappiness depends on the individual, particularly on his attitude, and not on outward causes such as low pay, long hours, boring work" (p. 55). Indeed, just as the structure and ideal of the ie superseded the importance of its individual members, the survival of the company also had to be ensured, even at the expense of "social relations or individual satisfactions" (p. 51).

While Meiji conservative elites had rearticulated the $i e$ alongside an imperial family-state ideology - reimagining Japanese society as a singular extended family bound together by a common imperial purpose - postwar political and business elites collaborated to reconsolidate the gendered and hierarchical social roles and identities of the $i e$ within Japan's postwar company culture. In doing so, they effectively placed the company at the center of a new collectivist family model that would support Japan's emerging enterprise society. Though the ie's legal foundation was officially removed from the postwar constitution, it ultimately remained a central ideological and discursive influence on Japan's collectivist subjectivities and social structures in the postwar period and beyond. 


\section{Conclusion}

In the Meiji and postwar periods, the conservative Japanese state articulated specific ideas of family and nation in order to perpetuate and exploit the feudal power relations and gendered and collectivist subjectivities that had previously upheld oligarchic power in Japan. In order to advance their own vision of Japanese society, they institutionalized a samurai family model, called the $i e$ family, and placed it at the center of a new family-state ideology that elevated the emperor as the father of all Japanese people. They then limited women's roles to the $i e$ through a teaching known as the "good wife, wise mother" ideology. In the postwar period, after the US-led occupation decided to reinstate conservative control of the government in order to reposition Japan as a bulwark against communism in East Asia, an ultraconservative prime minister promoted a corporate social management campaign that interpellated Japanese wives as professional housewives who would work for the sake of their husband and his occupation in much the same way as they had done in the ie. Meanwhile, husbands themselves would be so dedicated to their work as to essentially disappear from their homes, while companies strongly employed the principles and power relations of the $i e$ to manage employees. Japan's postwar nuclear family and the "company as family" model ultimately formed the foundation of a collectivist enterprise society, which itself essentially represented a new iteration of the previous imperial family-state.

This analysis clarifies the modern history of collectivist society in Japan; it highlights a close relationship between family and the state that has operated continually to support particular patriarchal power structures and collectivist subjectivities, while also revealing family to be a key site of power employed by Japan's conservative ruling elite in the Meiji and postwar periods. This challenging history suggests the broader need to examine the specificity of modernization within different cultures. While modernization may imply deterministic processes of westernization or liberalization, indigenous forces can influence it in important ways; "modernization" is thus a concept that should always elicit substantial scrutiny within specific cultural contexts. 
The Arbutus Review • $2019 \bullet$ Vol. 10, No. $1 \bullet$ https://doi.org/10.18357/tar101201918937

\section{References}

Beckmann, G. M. (1957). The making of the Meiji constitution: The oligarchs and the constitutional development of Japan, 1868-1891. Westport, CT: Greenwood Press.

Befu, H. (1962). Corporate emphasis and patterns of descent in the Japanese family. In R. Smith, K., Beardsley, \& National Academy of Sciences (Eds.), Japanese culture: Its development and characteristics. Paper presented at the subscribers, no. 34, pp. 34-41

Bowen, R. W. (2003). Japan's dysfunctional democracy: The Liberal Democratic Party and structural corruption. Armonk, NY: M.E. Sharpe.

Danshaku Motoda Nagazane. (n.d.). In Encyclopaedia Brittanica. Retrieved on April 16, 2019 from https://www.britannica.com/biography/Danshaku-Motoda-Nagazane

Dudden, A., \& Mizoguchi, M. (2007). Abe's violent denial: Japan's prime minister and the "comfort women." The Asia Pacific Journal: Japan Focus, 5(3). Retrieved from https://apjjf.org/Alexis-Dudden/2368/article.html

Eisenstein, Z. (1999). Constructing a theory of capitalist patriarchy and socialist feminism. Critical Sociology, 25(2-3), 196-217. doi:10.1177/08969205990250020901

Freeden, M., Stears, M., \& Norval, A. (2013). Poststructuralist conceptions of ideology. In The Oxford Handbook of Political Ideologies. Oxford, UK: Oxford University Press.

Freeden, M., Stears, M., \& Van Dijk, T. (2013). Ideology and discourse. In The Oxford Handbook of Political Ideologies. Oxford, UK: Oxford University Press.

Garon, S. (2010). State and family in modern Japan: A historical perspective. Economy and Society, 39(3), 317-336. doi:10.1080/03085147.2010.486214

Gluck, C., 1941. (1985). Japan's modern myths: Ideology in the late Meiji period. Princeton, NJ: Princeton University Press.

Gordon, A. (2014). A modern history of Japan: From Tokugawa times to the present (Third ed.). New York, NY: Oxford University Press.

Gordon, A. (1997). Managing the Japanese household: The New Life Movement in postwar Japan. Social Politics: International Studies in Gender, State 63 Society, 4(2), 245-283. doi:10.1093/sp/4.2.245

Harootunian, H. (1959). The progress of Japan and the samurai class, 1868-1882. Pacific Historical Review, 28(3), 255-266. doi:10.2307/3636470

Hayashi, K. (2006). "The public" in Japan. Theory, Culture ES Society, 23(2-3), 615-616. doi:10.1177/0263276406023002109

Howland, D. R. (2001). Samurai status, class, and bureaucracy: A historiographical essay. The Journal of Asian Studies, 60(2), 353-380. doi:10.2307/2659697

Jeong, D. Y., \& Aguilera, R. V. (2008). The evolution of enterprise unionism in Japan: A sociopolitical perspective. British Journal of Industrial Relations, 46(1), 98-132. doi:10.1111/j.14678543.2007.00668.x

Kitano, S. (1962). Dozoku and ie in Japan: The meaning of family genealogical relationships. In R. Smith, K., Beardsley, \& National Academy of Sciences (Eds.), Japanese culture: Its development and characteristics. Paper presented at the Subscribers, no. 34, pp. 42-46.

Kondo, D. K. (1990). I (2nd ed.). Chicago, IL: University of Chicago Press.

Lebra, T. (2007). Confucian gender role and personal fulfillment for Japanese women. In Identity, Gender, and Status in Japan (pp. 248-263) doi:10.1163/ej.9781905246175.i-439.127

Lee, Y. W. (2004). The origin of one party domination: America's reverse course and the emergence of the Liberal Democratic Party in Japan. The Journal of East Asian Affairs, 18(2), 371-413.

Mackie, V. C. (2003). Feminism in modern Japan: Citizenship, embodiment, and sexuality. Cambridge, UK: Cambridge University Press. 
MacKinnon, C. A. (1989). Toward a feminist theory of the state. Cambridge, Mass: Harvard University Press.

Matanle, P. C. D. (2003). Japanese capitalism and modernity in a global era: Re-fabricating lifetime employment relations. New York, NY: Routledge.

Molony, B. (2011). From "mothers of humanity" to "assisting the emperor": Gendered belonging in the wartime rhetoric of Japanese feminist Ichikawa Fusae. Pacific Historical Review, 80 (1), 1-27. doi:10.1525/phr.2011.80.1.1

Motoda Nagazane. (n.d.). In Portraits of modern Japanese historical figures. Retrieved on April 16, 2019 from https://www.ndl.go.jp/portrait/e/datas/202.html

Mouffe, C. (Ed.). (1979). Gramsci and Marxist theory. New York, NY: Routledge.

Nolte, S. H., \& Hastings, A. H. (1991). The Meiji state's policy toward women, 1890-1910. In G. L. Bernstein (Ed.), Recreating Japanese women, 1600-1945 (pp. 151-174). Berkeley, CA: University of California Press.

Osaki, T. (2019, July 22). Abe vows to push forward constitutional change despite failure of pro-revision forces to win Upper House supermajority. The Japan Times. Retrieved from https://www.japantimes.co.jp/news/2019/07/22/national/politics-diplomacy/abe-vowspush-forward-constitutional-change-despite-failure-pro-revision-forces-win-upper-house-super majority/\#.XTnbwiMrKiY

Prime ministers in history. (n.d.). Retrieved August 20, 2019, from https://japan.kantei.go.jp/cabinet/ 0001-30_e.html

Rohlen, T. P. (1974). For harmony and strength: Japanese white-collar organization in anthropological perspective. Berkeley, CA: University of California Press.

Sakuta, K. (1986). A reconsideration of the culture of shame (K. Yagi \& M. McKinney, Trans.). Review of Japanese Culture and Society, 1(1), 32-39.

Shizuko, K., \& Sylvain, G. A. (1994). The "good wife and wise mother" ideology in post-World War I Japan. U.S.-Japan Women's Journal. English Supplement, 7, 31-52.

Skya, W. (2009). Japan's holy war: The ideology of radical Shintō ultranationalism. Durham, NC: Duke University Press.

Sugimoto, Y., (2014). An introduction to Japanese society (4th ed.). Port Melbourne, Vic: Cambridge University Press.

Tabb, W. K. (1995). The postwar Japanese system: Cultural economy and economic transformation. New York, NY: Oxford University Press.

Ueno, C., (2009). The modern family in Japan: Its rise and fall. Melbourne, Vic: Trans Pacific Press.

Uno, K. S. (1991). Women and changes in the household division of labor. In G. L. Bernstein (Ed.), Recreating Japanese women, 1600-1945 (pp. 17-41). Berkeley, CA: University of California Press.

Yamane, T., \& Nonoyama, H. (1967). Isolation of the nuclear family and kinship organization in Japan: A hypothetical approach to the relationships between the family and society. Journal of Marriage and Family, 29(4), 783-796.

Yoshida, R. (2006, December 28). To fathom Abe, just look at his grandfather: Kishi pushed the agenda of today decades ago. The Japan Times. Retrieved from https://www.japantimes.co. $\mathrm{jp} /$ news/2006/12/28/national/to-fathom-abe-just-look-at-his-grandfather/\#.XTnWxCMrKiY 